\title{
Differentiated Learning Model For Student with Reading Difficulties
}

\begin{abstract}
Aldjon Nixon Dapa
\section{Info Artikel}

Sejarah Artikel:

Diterima: 9 Juni 2020

Direvisi: 10 Juli 2020

Dipublikasikan: Agustus 2020

e-ISSN: 2620-3081

p-ISSN: 1411-2744

DOI: $10.21009 / j$ tp.v22i2. 15814

Abstract: This research is an analytical-descriptive study which focuses on the characteristics of students with difficulties in reading and the needs for differentiated learning instruction. The result of this study reveals that the prevalence of Students with Difficulties in Reading reaches $9,15 \%$ of the total population of students from each elementary school in Tomohon. The most excellent ability in reading comprehension which students have achieved is the level of literal reading. Students who have this level of reading skill can only be found in two elementary schools. Of 10 elementary schools, only students from 4 elementary schools whose reading ability lies on the lowest level, that is understanding vocabulary. In general, students face the difficulties in understanding inference and applying vocabularies. Learning process which has recently used is inadequate to accommodate students' ability and solve their difficulties. The methods used in class include lectures and assignments. There are two methods, those are Rumpang Method and Glass analysis. The recent condition which students with difficulties in reading face requires immediate and meticulous problem solving. Therefore, teachers need to apply differentiated learning instruction in order to facilitate adaptive learning process suitable for the abilities of students with difficulties in reading.
\end{abstract}

Keywords: Differentiated learning instruction, students with difficulties in reading

(C) 2020 PPS Universitas Negeri Jakarta

\section{INTRODUCTION}

Learning difficulties are indicated by the inability/difficulty in language and mathematics. For students with normal or beyond average intelligence, they face difficulties to understand one or more subjects taught in class. They do not have problems or other disorders such mental retardation which hampers them to understand the subject.

IDEA has presented data on the total number of students with learning difficulties in America. These data which concentrate on children in school age have been collected from 2000 to 2001. From the data, it can be concluded that about 2,9 million students aged 6-21 years old experience difficulties in learning process. Hallahan, Kauffman, and Lloyd (1996: 47-49) claim that 5\% from total population of children in school age receive special training due to their learning difficulties. The percentage of children with learning difficulties tends to rise. From 1977 to 1978 , the percentage was less than $30 \%$ 
from total number of students who received specific education, and now the percentage increases for approximately $50 \%$.

Research conducted by Sudrajat, at al, (2020) about model development of response to intervention for children with disabilities in central jakarta inclusive schools, research results show that the module of the response to intervention model can be said to be good, but still needs to be improved in accordance with expert advice, as well as teachers as users.

Talking about the effectiveness of learning created in this research is inseparable from the collaboration of stakeholders in this case, researchers, principals, class teachers, special teacher assistants continuously and also the readiness of teachers in planning learning, preparing media and learning materials, as well as teacher's ability to manage class. This is like the research findings submitted by Rohmawati (2015) that, "(1) learning is effective because of the conditioning that is done continuously between the vision and mission of the school in achieving quality education, (2) the existence of readiness of teachers in planning learning and teachers' attitudes and capabilities in provide exemplary in children, (3) the success of parents in achieving effective learning in children can not be separated from their parents upbringing influenced by socioeconomic background of the family as well as the intensity of the time spent with the child, (4) the awareness of society in school success petrified organize effective learning, (5) the shape is done with the cooperation of stakeholders to establish communication and involvement in school activities."

Effective learning is closely related to maximum learning outcomes, or in other words effective learning is able to provide maximum learning outcomes for students. Effective learning can be achieved by effective teachers too. Raharjo (2014) in his article stated that the standard of educators and education personnel had a significant influence on the learning achievement of the National Examination.

In Indonesia, the effort to accurately record the number of students with learning difficulties has not been initiated. However, some teachers who involve in learning process in regular schools have reported that they have some students with learning difficulties in the class. Unfortunately, these teachers do not have enough understanding and comprehension on the characteristics and problems the students with learning difficulties face. As a result, these students do not get suitable and optimum treatment.

Elementary school students still have low reading habit. This tendency is shown in the survey about reading tradition of primary school students in the world. Indonesia was in the $30^{\text {th }}$ rank, while Finland is in the $1^{\text {st }}$ rank (Kurniawan, 2000: 237). Reading skill is the basic ability to master various subjects. If students in the primary education level are not trained to acquire reading skill, they obviously face difficulties in studying other disciplines in the higher classes (Abdurahman, 1999:200).

In fact the teacher as an innovator in learning in the classroom is required to have extensive knowledge about the characteristics and problems experienced by students who experience learning difficulties. This is as the result of Obonyo, Bin, and Maina research which shows that the level of education and teaching experience of teachers has a significant impact on student learning outcomes. (Obonyo, Bin \& Maina, 2018).

In general, education for children with learning disabilities in Indonesia is given by using a special educational approach. In Tomohon ,North Sulawesi Province, some schools have provided education services for students with learning disabilities, one of which is Sekolah Dasar Negeri II Tomohon. In this school, teachers teach students with learning disabilities by using learning method set for the needs of students. This method is also directed to facilitate problems in learning that students with learning disabilities might encounter. However, many teachers still use less structured strategy, method, and techniques and less systematic learning process. As a result, the result obtained is less optimum.

Less optimum result in learning process used to handle problems of children 
with learning disabilities occurs because teachers do not provide learning method which has been adjusted to fulfill students' interest and need. The result of the observation and interview shows that most teachers apply learning method which focuses on certain method and techniques (based on existing problems) to handle students with learning difficulties. However, this method does not consider students' interest, learning style, and way of thinking. As a result, students seem unmotivated, lazy, and passive when attending the class.

\section{RESEARCH METHOD}

This research uses descriptive-analytic method. By applying survey technique and case studies, the researcher sought to examine the status of a group of students with reading difficulties in the population of elementary students in Tomohon. This technique is useful to obtain accurate facts and data related to the condition and characteristics of ability of students with difficulties in reading.

The research subjects are students in grade 4,5, and 6 who have been identified to have difficulties in reading. The research subjects also include teachers and the headmaster. The research instrument developed by the researcher is instrument on identifying and assessing students with difficulties in reading. Before applied, the instrument has undergone validity and reliability tests which was conducted by the experts. Data obtained during observation and interview are analyzed in descriptive method and expressed in percentage.

\section{RESULT AND DISCUSSION}

\section{The Result of the Research}

a. Profiles of Students with Difficulties in Reading

In accordance to the research objective, data on the number or the percentage of students with difficulties in reading in some elementary schools as the research location are gathered in preliminary stage of the research. By using instruments on reading comprehension difficulties, the researcher presents those data that the prevalence of SBBM reaches $9,15 \%$. This percentage is obtained from the calculation after observing students of Grade 4,5, and 6 . Then, it is divided by the total number of students in one school. The lowest percentage is $6,5 \%$ in SD GMIM II Taratara. The result is low because the number of students in low grades is too many. The highest percentage is found in SD Inpres Uluindano which reaches $12 \%$. The number of Students with Difficulties in Reading found among the overall students in these 10 elementary schools exerts burden for the teachers. In addition, Students with difficulties in writing and counting also give another pressure for teachers.

The general characteristics of students' reading ability are expressed in Table 2. It shows that the highest ability for students is to understand reading text literally which is found in students in 2 elementary schools (SD Negeri 2 dan SD GMIM I). Of the students in 10 elementary schools, students in SD Inpres Tondagow, SD Inpres Pangolombian, SD Inpres Wailan, dan SD Inpres Uluindano have the lowest ability in reading, that is understanding vocabulary. In general, students face difficulties in reading inferences and application.

b. Method and Media Used by Teachers

The methods and media used by teachers during reading activities in class. These activities are learning process in Bahasa Indonesia class. In general, teachers use giving lecture and assigning task as the teaching methods. In SD GMIM Kinilow, SD GMIM II Tara-tara, and SD Negeri 2, teachers use two different methods, Metode Rumpang and Glass Analysis. The table also shows that teachers mainly use textbook as teaching media. Only few teachers use another source for teaching reading.

\section{DISCUSSION}

The number of students with difficulties in reading found in this study is significant. Theoretically, the prevalence of the number of 
students with learning difficulty in each class cannot precisely be determined; however, the estimation reaches 2-10\% [1]. As a quite prominent disability in regular schools, specific learning difficulties such as difficulty in learning mathematics (dyscalculia), difficulties in reading (dyslexia), and difficulties in writing (dysgraphia) have the significant prevalence reaching $8-9 \%$ from the total population of students in school (Joseph, 2005).

Most SBBM (Students with difficulty in learning) study in regular schools because their difficulties cannot be easily recognized. Therefore, they can enroll in regular schools. The surrounding environment, particularly teachers, does not even realize these students' weakness. The characteristic of learning difficulties lies on understanding vocabulary and its application. According to McNeil (Herson, 2004: 5), reading comprehension is to find information from the text. Then, the students combine these information with other elements such as their prior knowledge and experience into a new unity.

In selecting and applying instructional model, teachers tend to use methods that do not fit with the capabilities and characteristics of SBBM. Lectures and assignment are two conventional and boring methods. The more frequent use of these methods greatly influences the development of students' reading skill. Teachers have not applied more innovative learning model although they have known and applied it in teaching another subject. In teaching reading, teachers rarely use the innovative method; in other words, their learning method is monotonous. This statement supports opinion from [2] who states that teachers must be capable of organizing learning activities in class by applying individual learning program. This method enables the teachers to put more attention on the strength and weakness of each student. Teachers' misconception and less accurate teaching method exacerbate the difficulties in reading which students have already dealt with.

The introduction of a variety of innovative learning models becomes the responsibility for a teacher. Various developments that occur recently require adaptation treatment from the teacher, so they can perform more effective learning. This also supports [3] who states that various learning models have been available and applicative for language learning recently. Learning model for teaching has even been adopted to teach other subjects. Then, why do many teachers for Bahasa Indonesia still face difficulties to seek for various learning method to teach Bahasa Indonesia?. They also focus on teaching by using conventional methods such as lecture, discussion and assignments.

In general, many activities aiming at developing learning methods in which teachers often take a participation provide them an opportunity to know various innovative learning model. However, teachers in elementary schools in Tomohon have not known nor applied various learning models for differentiated learning instruction, in particular. According to [4], a variety of learning strategies can be performed to improve reading skill for students with difficulties in reading. Difficulty in reading is considered as a weakness that remains exist in students which hamper them to learn something. An appropriate learning model can overcome this problem. Therefore, [3] argues that teachers need to master and implement learning models which match the characteristics of SBBM.

There are several approaches, methods, and models which can be used to provide education for students with learning difficulties. Differentiated Instruction is a suitable method to overcome the problem. Differentiated Instruction takes the specific characteristics of the students into account and focuses on determining students' readiness, interest, thinking and learning styles. Student ability, interest, thinking and learning styles lead to/are adjusted with differentiation in the mastery of content, process, and product/result. Thus, teachers are compelled to change the method of teaching in which teachers treat all students in uniform treatment. The adjustment in learning material fosters students' critical thinking in learning process. In addition, this method provides opportunity for students with learning ability to demonstrate what they have 
studied in school. Differentiated Instruction enables students with learning difficulties to reach excellent academic achievement in class.

\section{CONCLUSION AND SUGGESTION}

\section{a. Conclusion}

Based on the activities in the research, there are some concluding remarks as follows:

The prevalence of $S B B M$ in reading reaches $9,15 \%$ from the population of students in each elementary school in Tomohon. The highest ability for students is to understand reading text literally which is found in students in 2 elementary schools. Of the students in 10 elementary schools, only students in 4 elementary school students have the lowest ability in reading, that is understanding vocabulary. In general, students face difficulties in reading inferences and application. In general, most common and most frequently-used factual learning instruction by the teachers are lectures and assignment. There are only two different methods, Metode Rumpang and Glass Analysis. Teachers have not comprehended and learnt specific learning instruction which is able to accommodate students with difficulties in reading. There are several approaches, methods, and models which can be used to provide education for students with learning difficulties. Differentiated Instruction is a suitable method to overcome the problem. Differentiated Instruction takes the specific characteristics of the students into account and focuses on determining students' readiness, interest, thinking and learning styles. Student ability, interest, thinking and learning styles lead to/are adjusted with differentiation in the mastery of content, process, and product/result. Thus, teachers are compelled to change the method of teaching in which teachers treat all students in uniform treatment. The adjustment in learning material fosters students' critical thinking in learning process. In addition, this method provides opportunity for students with learning ability to demonstrate what they have studied in school. Differentiated Instruction enables students with learning difficulties to reach excellent academic achievement in class.

\section{b. Suggestion and Recommendation}

Based on conclusion which has been exemplied before, the researcher give suggestion and recommendation as follows:

1) Teachers and the headmaster need to inititate socialization program about students with specific learning disabilities in various subjects such as reading, writing and mathematics.

2) This information needs immediate follow ups by providing guideline and training about differentiated learning instruction. The main objective is to guide teachers in performing effective learning for students.

\section{BIBLIOGRAPHY}

Abdurrahman, M. (2003). Pendidikan Bagi Anak Berkesulitan Belajar (cet. kedua). Jakarta: Depdikbud dan PT Rineka Cipta.

Delphie, B. (2006). Pembelajaran Anak Berkebutuhan Khusus: Dalam Setting Pendidikan Inklusi. Bandung: PT Refika Aditama.

Duke D Obonyo, Prof Chen Bin, G. F. M. (2018). Is Teacher Education Level and Experience Impetus for Student Achievement? Evidence from Public Secondary Schools in Kenya. American Journal of Educational Research and Reviews, 3(21), 14.

Lerner-Janet, W. (1989). Learning

Disablities: Theories, Diagnosis and

Teaching Strategis (Fifth ed.). Boston

USA: Houghton Mifflin Company.

Iskandarwassid \& Sunendar. (2008).

Strategi Pembelajaran Bahasa.

Bandung : Remaja Rosda Karya.

Mercer-Cecil, D. and Mercer-Ann, R. (1989). Teaching Students With Learning Problems (third ed.). Ohio USA: Merril Publishing Company A Bell \& Howell Company. 
Rohmawati, A. (2015). Efektivitas Pembelajaran. Jurnal Pendidikan Usia Dini, 9(1), 15-32.

Raharjo, S. B. (2014). Kontribusi Delapan Standar Nasional Pendidikan terhadap Pencapaian Prestasi Belajar. Jurnal Pendidikan dan Kebudayaan, 20(4), 470-482.

Somad, P .(2002). "Bimbingan Membaca Bagi Siswa Berkesulitan Membaca". Jurnal Jassi Anakku. 1. (1), 38-51.

Suyatno. (2004). Teknik Pembelajaran Bahasa dan Sastra. Surabaya : Penerbit SIC.

Shodiq, M. (1996). Pendidikan Bagi Anak berkesulitan belajar membacaa. Jakarta: Dirjen Dikti Depdikbud PPTA.

Suherman, Y. (2005). Adaptasi Pembelajaran Siswa Berkesulitan Belajar. Bandung: Rizqi Press.

Sunardi dan Sugiarmin, M. (2001). Identifikasi Karakteristik Perilaku Belajar Akademik Siswa Learning Disablities. Laporan Penelitian Dirjen Dikti Depdikbud Jakarta: tidak diterbitkan.

Sudrajat, Y., Siang, J. L., Marzuki, I., Wiyanti, E., Sari, N. W. A. P., Mufliharsi, Riza, \& Hanafi, H. (2020). Model Development of Response to Intervention for Children with Disabilities in Central Jakarta Inclusive Schools. Systematic Reviews in Pharmacy, 11(3), 651-656.

Wardani, I.G.A.K., Hernawati, T., Astati. (2007). Pengantar Pendidikan Luar Biasa. Jakarta: Universitas Terbuka. 2007 